\title{
Anti-inflammatory activity of raw and processed stingless bee honey
}

\author{
${ }^{1}$ Chong, K.Y., ${ }^{1, *}$ Chin, N.L., ${ }^{1}$ Yusof, Y.A. and ${ }^{2,3}$ Fakurazi, S. \\ ${ }^{1}$ Department of Process and Food Engineering, Faculty of Engineering, Universiti Putra Malaysia, 43400 \\ UPM Serdang, Selangor, Malaysia \\ ${ }^{2}$ Laboratory of Vaccines and Immunotherapeutics, Institute of Bioscience, Universiti Putra Malaysia, 43400 \\ UPM Serdang, Selangor, Malaysia \\ ${ }^{3}$ Department of Human Anatomy, Faculty of Medicine and Health Sciences, Universiti Putra Malaysia, \\ 43400 UPM Serdang, Selangor, Malaysia
}

\begin{abstract}
Article history:
Received: 10 April 2020

Received in revised form: 20

April 2021

Accepted: 21 April 2021

Available Online: 30 April

2021
\end{abstract}

Keywords:

Nitric oxide,

RAW 264.7,

Stingless bee honey,

Thermal processing,

Thermosonication

DOI:

https://doi.org/10.26656/fr.2017.5(S1).007

\begin{abstract}
The anti-inflammatory activity of raw and processed Kelulut stingless bee honey was investigated for its ability to inhibit nitric oxide (NO) production in lipopolysaccharidestimulated RAW 264.7 cells. Raw honey was optimally processed by thermal processing and thermosonication at $90^{\circ} \mathrm{C}$. The 3-(4,5-dimethylthiazol-2-yl)-2,5-diphenyl-tetrazolium bromide (MTT) cell viability assay showed that Kelulut honey from 7.8 to $500 \mu \mathrm{g} / \mathrm{mL}$ was not cytotoxic to RAW 264.7 cells as it resulted in at least $80 \%$ viable cells after $24 \mathrm{hr}$. Both raw and processed honey from 10 to $300 \mu \mathrm{g} / \mathrm{mL}$ displayed an increase and decrease in NO concentrations, suggesting a mixed effect of NO inhibition and enhancement. Maximum NO inhibition of $17.5 \%$ was recorded from $20 \mu \mathrm{g} / \mathrm{mL}$ of thermally processed honey while the highest NO enhancement of $7.8 \%$ was from $10 \mu \mathrm{g} / \mathrm{mL}$ of thermosonicated honey. The NO effects were independent of honey concentration and processing techniques, suggesting its potential robustness in medicinal properties as part of the diet.
\end{abstract}

\section{Introduction}

Honey consumption for its medicinal properties (Hadagali and Chua, 2014) is an example of a widespread shift from drugs to functional foods. Various studies have shown health-promoting properties of honey such as anti-inflammatory properties (Tonks et al., 2003; Kassim, Achoui, Mansor et al., 2010; Hadagali and Chua, 2014), antioxidant, and antibacterial properties (Liu et al., 2013). The Kelulut honey is commonly available in tropical climate forests of Malaysia and is produced by the stingless bee species from the Trigona spp. In comparison with other honey produced by Apis mellifera honey bees such as Acacia, Pineapple, Borneo, Gelam, Tualang, stingless bee honey has higher antioxidant activity, flavonoids, and polyphenol content (Rodríguez-Malaver, 2013; Ismail et al., 2016; Kek et al., 2017). Other bee products such as stingless bee propolis have also demonstrated antioxidant activity (Fikri et al., 2019). These bioactive compounds have been related to antioxidant properties (Ranneh et al., 2018), anti-bacterial properties (Zainol et al., 2013), and chemopreventive properties (Saiful Yazan et al., 2016), it is expected that Kelulut honey similarly contains antiinflammatory properties.

Preliminary studies of the anti-inflammatory properties of Kelulut honey are important to evaluate its feasibility and to suggest recommendations for main trials. Due to the costly experimental materials involved in biological studies, it is imperative to conduct trial batches. For example, a preliminary study was conducted on the anti-inflammatory effects of Tualang honey on rabbit eyes prior to the actual study (Bashkaran et al., 2011). As such, the context of this article is adapted as an introduction to the anti-inflammatory properties of raw and processed stingless bee honey. Inflammation is a natural response of tissue to injury or infection and it functions to protect and maintain the functional integrity of the body systems. However, prolonged inflammation has the potential of causing tissue injury in the form of fibrosis when the injury persists (Marcinkiewicz et al., 2004). Anti-inflammation refers to the property of a substance or treatment that reduces inflammation or swelling. It can be assessed by its mediators such as tumour necrosis factor- $\alpha$, interleukin, and nitric oxide 
(Tonks et al., 2003; Kassim, Achoui, Mansor et al., 2010). In this preliminary study, one of the mediators of inflammation, nitric oxide (NO) was investigated. NO is a product of macrophages activated by cytokines, microbial compounds or both. NO is synthesized from the amino acid, L-arginine, with the enzyme inducible NO synthase (iNOS) (Bogdan, 2001), and it aids in vasodilation and inhibition of platelet adhesion (Marcinkiewicz et al., 2004). However, prolonged and uncontrolled NO synthesis can cause sustained vasodilation, which could result in low blood pressure and septic shock (Nava et al., 1991). It is therefore important to control NO at acceptable levels.

Numerous prior studies examined the antiinflammatory effects of honey on different types of cells. As an example, Gelam honey extracts inhibited NO production when tested on murine fibrosarcoma cell line L929 and murine macrophage cell line RAW 264.7 (Kassim, Achoui, Mustafa et al., 2010). Gelam honey extracts were proven to reduce cytokine and NO levels (Kassim, Achoui, Mustafa et al., 2010). Additionally, most of the Taiwanese monofloral honey investigated inhibited interleukin-8 (IL-8) production of human colon carcinoma cell line WiDr (Liu et al., 2013). An increased expression of IL-8 is characteristic of many chronic inflammatory conditions. Moreover, Australian honey stimulated tumour necrosis factor- $\alpha$ (TNF- $\alpha)$ and interleukins in monocytes (Tonks et al., 2003). TNF- $\alpha$ and interleukin-1 $\beta$ are pro-inflammatory mediators, while interleukin-6 is an anti-inflammatory mediator (Tonks et al., 2003).

The objective of this preliminary study was to determine the effects of raw and processed Kelulut honey on the inhibition of NO production in RAW 264.7 cells. As raw Kelulut honey has high moisture content and easily ferments (Chong et al., 2017), this honey variety requires processing to extend its shelf life. Most honey processing techniques use heat treatment to sterilize honey and reduce its moisture content (Chua et al., 2014). Beyond the conventional heating process, thermosonication, which is the combination of heat and ultrasound waves, is a potential alternative processing method to improve the destruction of microorganisms. Ultrasound waves alone may not be very effective in destroying microorganisms unless when used at high intensities (Ahmed et al., 2009). Thermosonication has been explored as one of the minimal processing methods to remove moisture and improve the antioxidant activity of honey (Chong et al., 2017). Additionally, thermosonication inactivates deteriorative enzymes (Abid et al., 2014). Ultrasound treatment can also preserve and/or improve nutritional values and organoleptic properties of food (Chemat et al., 2011; Chaikham and Prangthip, 2015).

\section{Materials and methods}

\subsection{Materials}

Stingless bee honey, Kelulut, was supplied by a local bee honey collector from a forest in Teluk Intan, Perak, Malaysia. The multifloral honey was produced by Trigona spp. bees. The freshly harvested honey was obtained in January 2016 and was stored at $4{ }^{\circ} \mathrm{C}$ for experiments.

\subsection{Honey processing}

Thermosonication and thermal processing of honey were conducted according to optimized processing conditions (Chong et al., 2017). Honey weighing $20 \mathrm{~g}$ was filled into test tubes of $25 \mathrm{~mm}$ diameter and $150 \mathrm{~mm}$ height. An ultrasonic bath tank at $25 \mathrm{kHz}$ powered by piezoelectric flange-mounted type transducers (Branson Ultrasonics Co., Danbury, CT, USA) at $2.5 \mathrm{~kW}$ was fitted with heating element of $6 \mathrm{~kW}$ and insulation for a thermosonication effect. A test tube rack was suspended in the middle of the tank to hold the test tubes containing honey. For thermal processing, a thermostatic water bath (WNB 22, Memmert GmbH + Co. KG, Germany) was used. Thermosonication and thermal processing were performed at $90^{\circ} \mathrm{C}$ for $111 \mathrm{mins}$ and 108 mins, respectively as those were the optimized temperature and time which improved honey quality (Chong et al., 2017). Optimization was based on minimum water activity, moisture content, and hydroxymethylfurfural content and maximum colour intensity, viscosity, total phenolic content, and radical scavenging activity.

\subsection{Cell culture}

Murine macrophage cell line, RAW 264.7 (ATCC ${ }^{\circledR}$ TIB-71 ${ }^{\mathrm{TM}}$ ) was obtained from the Institute of Bioscience, Universiti Putra Malaysia. Cells were maintained in high glucose Dulbecco Modified Eagle Medium (DMEM) (Nacalai Tesque, Kyoto, Japan). It was supplemented with $10 \%$ fetal bovine serum and $1 \%$ penicillinstreptomycin. The flask underwent passage every 2 to 3 days with standard aseptic techniques.

\subsection{Cell viability assay}

Cell viability was evaluated with the 3-(4,5dimethylthiazol-2-yl)-2,5-diphenyltetrazolium bromide (MTT) colourimetric assay (Mosmann, 1983) with slight modifications. RAW 264.7 cells $(100 \mu \mathrm{L})$ per well were seeded using sterile 96-well microplates with a cell density of $1 \times 10^{4}$ cells per well. Cell density was measured using the Trypan Blue exclusion assay. After 
$24 \mathrm{hr}$ incubation at $37^{\circ} \mathrm{C}$ and $5 \% \mathrm{CO}_{2}$, the cells were treated with honey concentrations from 7.8 to $500 \mu \mathrm{g} /$ $\mathrm{mL}$. The control sample was incubated with media only. After treatment for $24 \mathrm{hr}, 20 \mu \mathrm{L}$ of $5 \mathrm{mg} / \mathrm{mL}$ MTT solution (Nacalai Tesque, Japan) was added. The cells were then incubated for 3 to $4 \mathrm{hr}$. Instead of overturning the plate over a sink which might result in crystal loss, the supernatant was aspirated and discarded. DMSO was added to solubilize formazan precipitate to form a purple solution. Absorbance was measured at $570 \mathrm{~nm}$ using a microplate absorbance reader (TECAN, Sunrise, Switzerland). The data was analyzed using its accompanying software Magellan Version 7.2. Cell viability was determined using Equation (1).

$$
\text { Cell viability }(\%)=\mathrm{A}_{\mathrm{S}} / \mathrm{A}_{\mathrm{C}} \times 100 \%
$$

Where $A_{S}$ and $A_{C}$ are the absorbance of sample and control, respectively.

\subsection{Nitric oxide inhibition assay}

RAW 264.7 cells were seeded in 12-well plates with a cell density of $5 \times 10^{5}$ cells per well with $1 \mathrm{~mL}$ of cell culture media and incubated for 15 to $16 \mathrm{hr}$. The media of each well were then aspirated and replaced with fresh DMEM. Based on the preceding MTT assay, cells were treated with the honey solution with non-cytotoxic concentrations of $10,20,50,100,200$, and $300 \mu \mathrm{g} / \mathrm{mL}$. Dexamethasone at $1 \mu \mathrm{g} / \mathrm{mL}$ was used as positive control while untreated cells were used as a negative control. After $2 \mathrm{hrs}$ of treatment, the cells were stimulated with lipopolysaccharide (LPS) with the final concentration of $1 \mu \mathrm{g} / \mathrm{mL}$ for each well. LPS stimulation was executed for all wells except for the control well which only contained cells and media. The plates were then incubated for $24 \mathrm{hrs}$ at $37^{\circ} \mathrm{C}$ and $5 \% \mathrm{CO}_{2}$. Following incubation, $\mathrm{NO}$ inhibition was assessed by quantifying nitrite released in the culture medium via Griess reagent which consisted of $0.1 \% \quad(\mathrm{w} / \mathrm{v}) \quad \mathrm{N}-1-$ naphthyl ethylenediamine dihydrochloride (NED), 1\% (w/v) sulfanilamide, and $2.5 \%(\mathrm{v} / \mathrm{v})$ phosphoric acid. Cell supernatant of $100 \mu \mathrm{L}$ from treated and untreated wells was mixed with an equal volume of Griess reagent in a 96-well plate and was incubated at room temperature for $10 \mathrm{~min}$ in the dark. The resulting colour was measured at $540 \mathrm{~nm}$ with a microplate reader (TECAN, Sunrise, Switzerland). The absorbance values were compared to a standard sodium nitrite curve with concentrations from 1.6 to $200 \mu \mathrm{M}$. The percentage of NO inhibition was calculated following Equation (2) (Tsai et al., 2005). Negative values obtained from this equation were considered as enhancement of NO.

$$
\text { Nitric oxide inhibition }=\left(1-\frac{\mathrm{NO}_{\text {sample }}-\mathrm{NO}_{\text {control }}}{\mathrm{NO}_{\mathrm{LPS}}-\mathrm{NO}_{\text {control }}}\right) \times 100 \%
$$

\subsection{Statistical analysis}

The experiments comprised of three independent experiments and they were performed in triplicates. Results were expressed as mean \pm standard error. Error bars in graphs represent standard error of means. Oneway analysis of variance (ANOVA) was used to test for significant differences $(p<0.05)$ between means using Tukey's multiple comparison test.

\section{Results and discussion}

\subsection{Effect of raw and processed Kelulut honey on cell viability}

Figure 1 shows that Kelulut honey concentrations from 7.8 to $500 \mu \mathrm{g} / \mathrm{mL}$ which was previously treated using thermal processing and thermosonication, did not cause any significant cytotoxicity in RAW 264.7 cells in all the concentrations tested. Cell viability was observed to be above $80 \%$ for all concentrations tested. Hence, these honey were not cytotoxic towards RAW 264.7 cells. This assay is essential to isolate the influence of concentration on cytotoxicity during subsequent experiments.

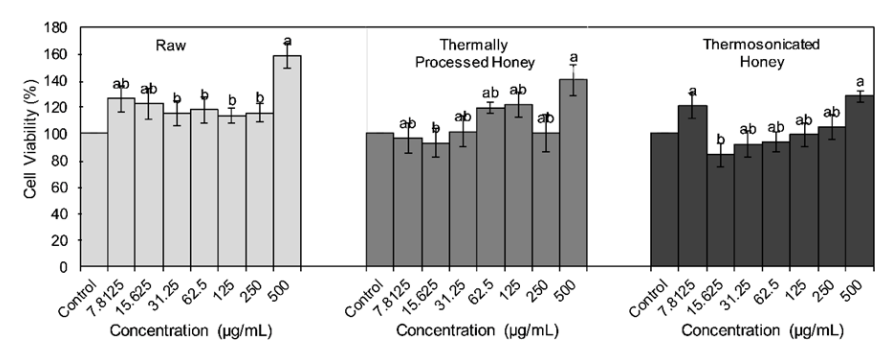

Figure 1. Effect of different honey concentrations on viability of RAW 264.7 cells. Bars with different letters above in the same honey category are significantly different $(P<0.05)$.

Figure 1 shows that raw honey enhanced the growth of RAW 264.7 cells. Honey is well known for promoting wound healing by rapid debridement, which is the replacement of sloughs with granulation tissue. Honey also speeds up epithelialization and facilitates absorption of edematous fluids around wounds which can help to reduce swelling (Molan, 2001). Similarly, honey had a stimulatory effect on the proliferation of rat fibroblast cell line (Al-Jadi, Enchang, and Yusoff, 2014). In addition, the stimulatory effect was dose and timedependent. Most growth factors had the greatest stimulatory effect at a specified dose and must be released at the right moment. In a clinical study by Postmes et al. (1997), the effects of honey, sugar, and silver sulfadiazine (SSD), a common ointment used to treat burns, were investigated on the healing of deep second degree burns on Yorkshire pigs. Honey performed better than SSD due to its quick reepithelialisation and absence of sustained inflammatory 
reaction. Honey was better than sugar paste as a result of its natural antibacterial activity. In our study, sugars present in Kelulut honey may improve RAW 264.7 cell proliferation as it is an energy source. In thermosonicated honey at $15.6 \mu \mathrm{g} / \mathrm{mL}$, there was a slight decline in cell viability of $84 \%$. This may be due to sonodegradation of honey due to the generation of minimal free radicals from sonication at low frequencies (Ahmed et al., 2009). These free radicals can cause cell damage and death. For thermally processed honey, cell growth was stimulated in the presence of honey.

\subsection{Effect of raw and processed Kelulut honey on nitric oxide inhibition}

Nitric oxide is a mediator of inflammation. It functions as a tumoricidal and antimicrobial molecule in vitro and in vivo (Bogdan, 2001) and aids in vasodilation (Marcinkiewicz et al., 2004). However, prolonged and uncontrolled nitric oxide synthesis can cause serious health problems (Nava et al., 1991). Thus, it is important to control nitric oxide at acceptable levels. The potential anti-inflammatory properties of Kelulut honey were investigated by evaluating the effects on NO inhibition in RAW 264.7 cells stimulated with LPS. In Figure 2, the control well represented RAW 264.7 cells only while the bars labelled with 'LPS' indicates that cells were stimulated with LPS to induce NO production. Dexamethasone was used as a positive control as it is a common anti-inflammatory drug.

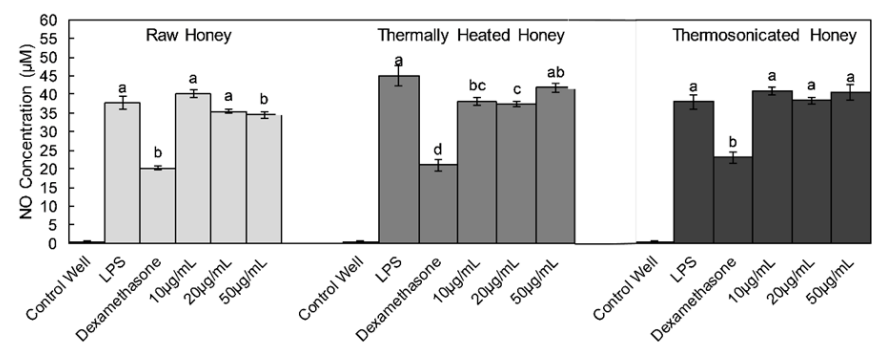

Figure 2. Effects of low honey concentrations on NO production of RAW 264.7 cells. Bars with different letters above in the same honey category are significantly different $(P<0.05)$.

Figure 2 shows that NO levels increased up to 37.6, 38.0, and $45.1 \mu \mathrm{M}$ for raw honey, thermosonicated honey, and thermally processed honey, respectively after 15 to $16 \mathrm{hrs}$ of LPS stimulation. Incubation of reaction mixture with dexamethasone (positive control) reduced NO levels compared to RAW 264.7 cells induced with LPS in all treatments. For raw Kelulut honey, a reduction in NO was observed and it was only significant at $50 \mu \mathrm{g} /$ $\mathrm{mL}$. For thermally processed honey, NO reduction occurred but more significantly different than the LPSstimulated cells at 10 and $20 \mu \mathrm{g} / \mathrm{mL}$. For thermosonicated honey, there were increases in NO concentrations, but they were not significant.
Figure 3 shows the effect of higher honey concentrations at 100, 200, and $300 \mu \mathrm{g} / \mathrm{mL}$ on $\mathrm{NO}$ production of the cells. Honey at these concentrations exhibits both NO inhibition and enhancement. The cells stimulated with LPS recorded lower readings of NO concentration. This may be due to storage duration as LPS is a very sensitive chemical. In another study involving RAW 264.7 cells, the addition of LPS stimulated significantly different NO levels, which was a ten-fold difference (Jung et al., 2013). In this study, a different batch of LPS was used for the cells with higher honey concentration. This resulted in lower NO concentrations ranging from 15.6 to $17.4 \mu \mathrm{M}$. Thus, the percent inhibition values calculated as presented in Table 1 are more appropriate to indicate the inhibitory effects compared to NO concentrations. Table 1 shows that lower honey concentrations at 10,20 , and $50 \mu \mathrm{g} / \mathrm{mL}$ yielded NO inhibition ranging from 5.9 to $17.5 \%$ and NO enhancement range from 1.0 to $7.8 \%$. Honey at higher concentrations at 100, 200, and $300 \mu \mathrm{g} / \mathrm{mL}$ resulted in NO inhibition ranging from 0.4 to $15.6 \%$ and NO enhancement of 3.4 to $7.3 \%$.

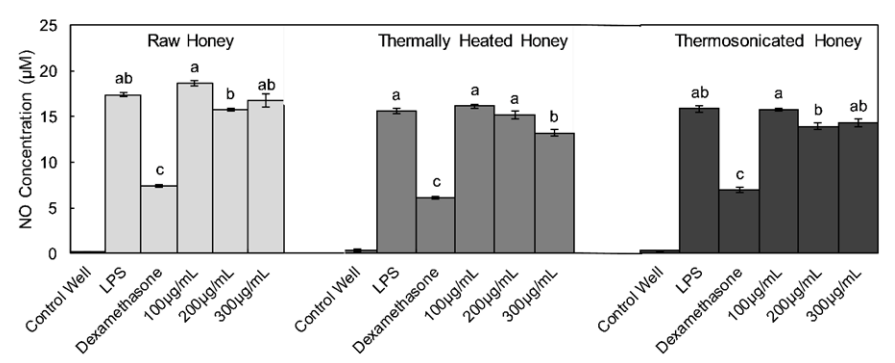

Figure 3. Effects of higher honey concentrations on NO production of RAW 264.7 cells. Bars with different letters above in the same honey category are significantly different $(P<0.05)$.

Inflammation is a natural response to injury which can be triggered by external injuries, bacteria invasion, chemical exposure, or radiation (Clancy, 1998). The body attempts to restore the tissue to its preinjury state (Serhan et al., 2010). Physically, acute inflammation is characterized by rubor (redness), calor (heat), tumour (swelling), and dolour (pain). Internally, inflammation is characterized by an increased blood flow to the affected area to dilute possible toxic agents, increased capillary permeability, and migration of leukocytes, or commonly known as white blood cells. To resolve the inflammation and avoid chronic inflammation, inflammatory mediators function as secretory molecules produced by one cell that affect cell chemotaxis, cell activation, or cell proliferation, of that same cell or the adjacent cell. In these situations, cytokines will be present as the signalling molecules. Examples of inflammatory cytokines are interleukin, tumour necrosis factor- $\alpha$ (TNF $-\alpha$ ), transforming growth factor $\beta$ (TGF- $\beta$ ), and plateletderived growth factor (PDGF) (Clancy, 1998). As 
Table 1. Percent inhibition of NO using different honey concentrations

\begin{tabular}{cccc}
\hline \multirow{2}{*}{$\begin{array}{c}\text { Concentration } \\
(\mu \mathrm{g} / \mathrm{mL})\end{array}$} & \multicolumn{3}{c}{ Percent Inhibition $(\%)^{\dagger}$} \\
\cline { 2 - 4 } & Raw Honey & Thermally processed honey & Thermosonicated honey \\
\hline 10 & $-6.8 \pm 2.7(\mathrm{n}=14)^{\mathrm{b}}$ & $15.4 \pm 2.4(\mathrm{n}=13)^{\mathrm{ab}}$ & $-7.8 \pm 2.8(\mathrm{n}=13)^{\mathrm{b}}$ \\
20 & $5.9 \pm 1.4(\mathrm{n}=15)^{\mathrm{a}}$ & $17.5 \pm 1.7(\mathrm{n}=15)^{\mathrm{a}}$ & $-1.0 \pm 2.4(\mathrm{n}=12)^{\mathrm{ab}}$ \\
50 & $8.3 \pm 2.4(\mathrm{n}=14)^{\mathrm{a}}$ & $7.5 \pm 2.4(\mathrm{n}=14)^{\mathrm{bc}}$ & $-6.7 \pm 5.8(\mathrm{n}=12)^{\mathrm{b}}$ \\
100 & $-7.3 \pm 1.7(\mathrm{n}=9)^{\mathrm{b}}$ & $-3.4 \pm 1.7(\mathrm{n}=8)^{\mathrm{d}}$ & $0.4 \pm 1.3(\mathrm{n}=9)^{\mathrm{ab}}$ \\
200 & $10.0 \pm 1.0(\mathrm{n}=9)^{\mathrm{a}}$ & $2.5 \pm 3.4(\mathrm{n}=8)^{\mathrm{cd}}$ & $12.3 \pm 3.2(\mathrm{n}=9)^{\mathrm{a}}$ \\
300 & $4.1 \pm 5.5(\mathrm{n}=9)^{\mathrm{ab}}$ & $15.6 \pm 3.4(\mathrm{n}=8)^{\mathrm{ab}}$ & $9.6 \pm 2.8(\mathrm{n}=9)^{\mathrm{a}}$ \\
\hline
\end{tabular}

${ }^{\dagger}$ negative percent inhibition values indicate enhancement of $\mathrm{NO}$

mentioned in the introduction section, NO is a product of macrophages activated by cytokines, microbial compounds or both. Thus, fluctuating NO levels is akin to the body trying to maintain homeostasis.

In another study, Gelam honey extracts with concentration ranging from 3.125 to $100 \mu \mathrm{g} / \mathrm{mL}$ exhibited NO inhibition in RAW 264.7 cells (Kassim et al., 2010). The highest inhibition percentages were $80 \%$ and $40 \%$ for honey ethyl acetate extract and honey methanol extract, respectively. This difference may be due to the honey samples used because phenolic extracts were used in their study while crude honey was used in the present study. Fluctuation in NO production may be caused by the presence of amino acids in honey. The amino acid, L-arginine, is a precursor for NO production. As an example, Spanish honey contained various amino acids such as glutamic acid (Hermosín et al., 2003). The main amino acids in the honey are proline, lysine, tyrosine, and phenylalanine while lesser but equally important amino acids are arginine and glutamic acid. The complex metabolic pathway leading to the production of NO involves proline oxidase catalyzing proline into L-arginine in a series of steps. L-arginine is then metabolized into nitric oxide with the release of Lcitrulline (Wu and Morris, 1998). Although proline is not included in the Codex standard for honey quality control, it is a criterion of honey ripeness and an indication of sugar adulteration if it falls below a specific value. A minimum value of $180 \mathrm{mg}$ proline $/ \mathrm{kg}$ honey is considered genuine honey (Bogdanov et al., 1999). The distribution of NO metabolites in honey had positive and significant correlations between total protein, total phenols, and nitrate levels in those honey (Beretta et al., 2010). NO metabolites consist of nitrates and nitrites. In fact, nitrite content in Peruvian stingless bee honey ranged from 0.30 to $2.88 \mu$ moles nitrite $/ 100 \mathrm{~g}$ honey (Rodríguez-Malaver et al., 2009). Interestingly, when an artificial honey control was concocted using various sugars, it resulted in no nitrite content. Kelulut honey was compared to various Malaysian honey, manuka honey, and commercial honey (Kek et al., 2017). The authors reported that Kelulut honey had the highest protein content which was $0.85 \mathrm{~g}$ protein $/ 100 \mathrm{~g}$ honey among the tested samples. Therefore, NO enhancement of Kelulut honey observed may be attributed to existing amino acids or nitrites in the honey itself.

Similarly, fresh unprocessed honey and darker honey contained more NO metabolites (Al-Waili, 2003). Honey heated to $80^{\circ} \mathrm{C}$ for $1 \mathrm{hr}$ proved a reduction in total NO metabolites for all samples. Intravenous infusion of honey increased urinary NO metabolites in healthy sheep (Al-Waili, 2003). These increments could be due to the NO content in honey, or possible existence of NO synthase in honey, or the existence of substances that activated NO synthase to produce more NO (Al-Waili, 2003). Another study by the same author revealed that ingestion of honey solution increased nitrite content in saliva, plasma, and urine samples of healthy adult volunteers (Al-Waili and Boni, 2004). The same author probed further and discovered that honey solution increased total urinary nitrite content in healthy individuals (Al-Waili, 2005). Interestingly, artificial honey decreased urinary nitrite.

Although NO increment is very important for physiological aspects, too high NO concentration leads to chronic inflammation. The immunomodulatory effects of honey were further supported by a study using stingless bee honey from Costa Rica (Zamora, 2015). They revealed that these samples inhibited xanthine oxidase-mediated inflammation responses. The samples also scavenged reactive oxygen species (ROS) produced by human leucocytes. Hence, the raw, thermally processed, and thermosonicated Kelulut honey demonstrated both NO inhibition and enhancement effects in RAW 264.7 cells at concentrations of 10, 20, and $50 \mu \mathrm{g} / \mathrm{mL}$. At higher concentrations of 100, 200, and $300 \mu \mathrm{g} / \mathrm{mL}$, the honey mostly demonstrated NO inhibition.

Numerous studies have shown that honey has healthpromoting properties. Honey processing is vital to extend its shelf life and to diversify its application in other end products such as food supplements, cosmetics formulation, and packaging materials. It is important to evaluate the effects of honey processing on its efficacy, 
particularly on its anti-inflammatory properties. This preliminary study demonstrated that NO inhibition was independent of concentration for raw, thermosonicated, and thermally processed Kelulut honey when concentrations of $10,20,50,100,200$, and $300 \mu \mathrm{g} / \mathrm{mL}$ were tested. By comparing the percentage of inhibition of NO, thermally processed honey performed better when compared to raw honey and thermosonicated honey as it recorded an inhibition of $17.5 \%$. It is suggested that Kelulut honey may be a potential immunomodulator as it was able to both inhibit and enhance NO levels. The present study suggests the need for further studies by including other inflammation mediators such as tumour necrosis factor- $\alpha(\mathrm{TNF}-\alpha)$ and interleukins. Additionally, in-vivo studies are recommended to elucidate the inhibition and enhancement of NO production.

\section{Acknowledgements}

The authors thank Dr Palanisamy Arulselvan for the assistance given during the cell culture process and $\mathrm{Dr}$ Leslie Than Thian Lung for assistance in proofreading this paper.

\section{References}

Abid, M., Jabbar, S., Hu, B., Hashim, M.M., Wu, T., Lei, S., Khan, M.A. and Zeng, X. (2014). Thermosonication as a potential quality enhancement technique of apple juice. Ultrasonics Sonochemistry, 21(3), 984-990. https://doi.org/10.1016/ j.ultsonch.2013.12.003

Ahmed, J., Ramaswamy, H.S., Kasapis, S. and Boye, J.I. (2009). Novel food processing: effects on rheological and functional properties. USA: CRC Press.

Al-Jadi, A.-M., Enchang, F.K. and Yusoff, K.M. (2014). The effect of Malaysian honey and its major components on the proliferation of cultured fibroblasts. Turkish Journal of Medical Sciences, 44 (5), 733-740. https://doi.org/10.3906/sag-1303-43

Al-Waili, N.S. (2003). Identification of nitric oxide metabolites in various honeys: effects of intravenous honey on plasma and urinary nitric oxide metabolites concentrations. Journal of Medicinal Food, 6(4), 359 -364. https://doi.org/10.1089/109662003772519921

Al-Waili, N.S. (2005). Effects of Honey on the Urinary Total Nitrite and Prostaglandins Concentration. International Urology and Nephrology, 37(1), 107111. https://doi.org/10.1007/s11255-004-0871-8

Al-Waili, N.S. and Boni, N.S. (2004). Honey increased saliva, plasma and urine content of total nitrite concentrations in normal individuals. Journal of
Medicinal Food, 7(3), 377-380. https:// doi.org/10.1089/jmf.2004.7.377

Bashkaran, K., Zunaina, E., Bakiah, S., Sulaiman, S.A., Sirajudeen, K.N.S. and Naik, V. (2011). Antiinflammatory and antioxidant effects of Tualang honey in alkali injury on the eyes of rabbits: Experimental animal study. BMC Complementary and Alternative Medicine, 11(1), 90-100. https:// doi.org/10.1186/1472-6882-11-90

Beretta, G., Gelmini, F., Lodi, V., Piazzalunga, A. and Maffei Facino, R. (2010). Profile of nitric oxide (NO) metabolites (nitrate, nitrite and $\mathrm{N}$-nitroso groups) in honeys of different botanical origins: Nitrate accumulation as index of origin, quality and of therapeutic opportunities. Journal of Pharmaceutical and Biomedical Analysis, 53(3), 343 -349. https://doi.org/10.1016/j.jpba.2010.04.010

Bogdan, C. (2001). Nitric oxide and the immune response. Nature Immunology, 2(10), 907-916. https://doi.org/10.1038/ni1001-907

Bogdanov, S., Lüllmann, C., Martin, P., von der Ohe, W., Russmann, H., Vorwohl, G., Oddo, L.P., Sabatini, A.-G., Marcazzan, G.L., Piro, R., Flamini, C., Morlot, M., Lheritier, J., Borneck, R., Marioleas, P., Tsigouri, A., Kerkvliet, J., Ortiz, A., Ivanov, T., D'Arcy, B., Mossel, B. and Vit, P. (1999). Honey quality and international regulatory standards: review by the International Honey Commission. Bee World, 80(2), 61-69. https:// doi.org/10.1080/0005772X.1999.11099428

Chaikham, P. and Prangthip, P. (2015). Alteration of antioxidative properties of longan flower-Honey after High pressure, ultra-sonic and thermal processing. Food Bioscience, 10, 1-7. https:// doi.org/10.1016/j.fbio.2015.01.002

Chemat, F., Zill-e-Huma and Khan, M.K. (2011). Applications of ultrasound in food technology: Processing, preservation and extraction. Ultrasonics Sonochemistry, 18(4), 813-835. https:// doi.org/10.1016/j.ultsonch.2010.11.023

Chong, K.Y., Chin, N.L. and Yusof, Y.A. (2017). Thermosonication and optimization of stingless bee honey processing. Food Science and Technology International, 23(7), 608-622. https:// doi.org/10.1177/1082013217713331

Chua, L.S., Adnan, N.A., Abdul-Rahaman, N.L. and Sarmidi, M.R. (2014). Effect of thermal treatment on the biochemical composition of tropical honey samples. International Food Research Journal, 21 (2), 773-778.

Clancy, J. (1998). Basic concepts in immunology: a student's survival guide. New York, USA: McGraw 
Hill Professional.

Fikri, A.M., Sulaeman, A., Marliyati, S.A. and Fahrudin, M. (2019). Antioxidant activity and total phenolic content of stingless bee propolis from Indonesia. Journal of Apicultural Science, 63(1), 139-147. https://doi.org/10.2478/jas-2019-0012

Hadagali, M.D. and Chua, L.S. (2014). The antiinflammatory and wound healing properties of honey. European Food Research and Technology, 239(6), 1003-1014. https://doi.org/10.1007/s00217014-2297-6

Hermosín, I., Chicón, R.M. and Dolores Cabezudo, M. (2003). Free amino acid composition and botanical origin of honey. Food Chemistry, 83(2), 263-268. https://doi.org/10.1016/S0308-8146(03)00089-X

Ismail, N.I., Abdul Kadir, M.R., Mahmood, N.H., Singh, O.P., Iqbal, N. and Zulkifli, R.M. (2016). Apini and Meliponini foraging activities influence the phenolic content of different types of Malaysian honey. Journal of Apicultural Research, 55(2), 137-150. https://doi.org/10.1080/00218839.2016.1207388

Jung, S.-H., Kim, S. J., Jun, B.-G., Lee, K.-T., Hong, S.P., Oh, M. S., Jang, D.S. and Choi, J.-H. (2013). $\alpha-$ Cyperone, isolated from the rhizomes of Cyperus rotundus, inhibits LPS-induced COX-2 expression and PGE2 production through the negative regulation of NFKB signalling in RAW 264.7 cells. Journal of Ethnopharmacology, 147(1), 208-214. https://doi.org/10.1016/j.jep.2013.02.034

Kassim, M., Achoui, M., Mansor, M. and Yusoff, K.M. (2010). The inhibitory effects of Gelam honey and its extracts on nitric oxide and prostaglandin E2 in inflammatory tissues. Fitoterapia, 81(8), 1196-1201. https://doi.org/10.1016/j.fitote.2010.07.024

Kassim, M., Achoui, M., Mustafa, M.R., Mohd, M.A. and Yusoff, K.M. (2010). Ellagic acid, phenolic acids and flavonoids in Malaysian honey extracts demonstrate in vitro anti-inflammatory activity. Nutrition Research, 30(9), 650-659. https:// doi.org/10.1016/j.nutres.2010.08.008

Kek, S.P., Chin, N.L., Tan, S.W., Yusof, Y.A. and Chua, L.S. (2017). Classification of Honey from Its Bee Origin via Chemical Profiles and Mineral Content. Food Analytical Methods, 10(1), 19-30. https:// doi.org/10.1007/s12161-016-0544-0

Liu, J.-R., Ye, Y.-L., Lin, T.-Y., Wang, Y.-W. and Peng, C.-C. (2013). Effect of floral sources on the antioxidant, antimicrobial and anti-inflammatory activities of honeys in Taiwan. Food Chemistry, 139 (1-4), 938-943. https://doi.org/10.1016/ j.foodchem.2013.02.015

Marcinkiewicz, E., Marcinkiewicz, J. and Chłopicki, S.
(2004). Nitric oxide - a pro-inflammatory and antiinflammatory mediator. Central European Journal of Immunology, 28(2), 74-78.

Molan, P. (2001). Why honey is effective as a medicine. Bee World, 82(1), 22-40. https:// doi.org/10.1080/0005772X.2001.11099498

Mosmann, T. (1983). Rapid colorimetric assay for cellular growth and survival: Application to proliferation and cytotoxicity assays. Journal of Immunological Methods, 65(1), 55-63. https:// doi.org/10.1016/0022-1759(83)90303-4

Nava, E., Palmer, R.M.J. and Moncada, S. (1991). Inhibition of nitric oxide synthesis in septic shock: how much is beneficial? The Lancet, 338(8782), 1555-1557. https://doi.org/10.1016/0140-6736(91) 92375-C

Postmes, T.J., Bosch, M.M.C., Dutrieux, R., van Baare, J. and Hoekstra, M.J. (1997). Speeding Up the Healing of Burns with Honey. In Mizrahi, A. and Lensky, Y. (Eds.), Bee Products: Properties, Applications and Apitherapy, p. 57-63. Boston, USA: Springer US. https://doi.org/10.1007/978-14757-9371-0_6

Ranneh, Y., Ali, F., Zarei, M., Akim, A.M., Hamid, H.A. and Khazaai, H. (2018). Malaysian stingless bee and Tualang honeys: A comparative characterization of total antioxidant capacity and phenolic profile using liquid chromatography-mass spectrometry. LWT Food Science and Technology, 89(Supplement C), 1 -9. https://doi.org/10.1016/j.lwt.2017.10.020

Rodríguez-Malaver, A. (2013). Antioxidant Activity of Pot-Honey. In Vit, P., Pedro, S.R.M. Pedro and Roubik, D. (Eds.), Pot-Honey, p. 475-480. New York: Springer. https://doi.org/10.1007/978-1-46144960-7_34

Rodríguez-Malaver, A.J., Rasmussen, C., Gutiérrez, M.G., Gil, F., Nieves, B. and Vit, P. (2009). Properties of honey from ten species of Peruvian stingless bees. Natural Product Communications, 4 (9), 1221-1226. https:// doi.org/10.1177/1934578X0900400913

Saiful Yazan, L., Muhamad Zali, M.F.S., Mohd Ali, R., Zainal, N.A., Esa, N., Sapuan, S., Yong, S.O., Yin, S.T., Gopalsamy, B., Fui, L.V. and Syed Alwi, S.S. (2016). Chemopreventive Properties and Toxicity of Kelulut Honey in Sprague Dawley Rats Induced with Azoxymethane. BioMed Research International, 2016, $4036926 . \quad \mathrm{https} / / /$ doi.org/10.1155/2016/4036926

Serhan, C.N., Ward, P.A. and Gilroy, D.W. (2010). Fundamentals of inflammation. United Kingdom: Cambridge University Press. https://doi.org/10.1017/ 
CBO9781139195737

Tonks, A.J., Cooper, R.A., Jones, K.P., Blair, S., Parton, J. and Tonks, A. (2003). Honey stimulates inflammatory cytokine production from monocytes. Cytokine, 21(5), 242-247. https://doi.org/10.1016/ S1043-4666(03)00092-9

Tsai, T.-H., Tsai, P.-J. and Ho, S.-C. (2005). Antioxidant and Anti-inflammatory Activities of Several Commonly Used Spices. Journal of Food Science, 70(1), C93-C97. https://doi.org/10.1111/j.13652621.2005.tb09028.x

Wu, G. and Morris, S.M. (1998). Arginine metabolism: nitric oxide and beyond. Biochemical Journal, 336 (1), 1-17. https://doi.org/10.1042/bj3360001

Zainol, M., Mohd Yusoff, K. and Mohd Yusof, M. (2013). Antibacterial activity of selected Malaysian honey. BMC Complementary and Alternative Medicine, 13(1), 129-138. https:// doi.org/10.1186/1472-6882-13-129

Zamora, G. (2015). The antioxidant capacity and immunomodulatory activity of stingless bee honeys proceeding from Costa Rica. Oxidants and Antioxidants in Medical Science, 4(1), 49-55. https:// doi.org/10.5455/oams.180415.or.084 